\title{
Penggunaan Strategi Group Mapping Activities (Gma) Dalam Meningkatkan Kemampuan Membaca Siswa
}

\section{N. Anisah1*, K. S. Piscayanti², I. M. M. Yudana ${ }^{3}$}

${ }^{123}$ Jurusan Pendidikan Bahasa Inggris Universitas Pendidikan Ganesha

\section{ART I CLE I N F O}

Received January 21, 202

Revised February 03, 2021

Accepted April 08, 2021

Available online May 25, 2021

\section{Kata Kunci:}

Penelitian Tindakan Kelas,

Strategi GMA

Keywords:

Classroom Action Research,

GMA Strategy
Article history:

\begin{abstract}
A B S T R A K
Menguasai kemampuan membaca bahasa inggris menjadi hal yang tidak dapat dilakukan dengan mudah, khususnya bagi peserta didik di tingkat SMA. Hal ini jugalah yang ditemukan oleh peneliti saat melakukan pengamatan awal di salah satu kelas di SMA Negeri 3 Singaraja. Peneliti menemukan bahwa hampir seluruh peserta didik di kelas tersebut mengalami kesulitan dalam menemukan ide pokok, menemukan informasi rinci, dan memahami keseluruhan isi teks yang mereka baca. Dengan demikian, sangatlah penting bagi guru untuk dapat memilih strategi pembelajaran yang tepat bagi peserta didik. Salah satu strategi yang dapat digunakan adalah strategi Group Mapping Activities (GMA). Lebih lanjut, melalui penelitian tindakan kelas, peneliti bermaksud untuk mendeskripsikan pengimlementasian strategi GMA di dalam kelas tersebut. Selain itu, peneliti juga bermaksud untuk membuktikan bahwa strategi tersebut dapat membantu peserta didik dalam meningkatkan kemampuan membaca bahasa inggris mereka yang meliputi kemampuan menemukan informasi rinci dan memahami keseluruhan isi dari teks yang dibaca. Hasil penelitian menunjukkan bahwa pengimplementasian strategi Group Mapping Activities di kelas tersebut benar-benar dapat membantu peserta didik dalam meningkatkan kemampuan membaca bahasa inggris mereka. Hal ini ditunjukkan dari hasil post-test 1 dan 2 mereka yang meningkat
\end{abstract} dan telah mencapai nilai KKM. Selain itu, kesimpulan ini didasarkan pada hasil pengamatan di dalam kelas dan kuisioner yang menunjukkan respon positif peserta didik terhadap strategi yang digunakan pada saat pembelajaran bahasa inggris di dalam kelas.

\begin{abstract}
A BS TRACT
Mastering reading skill could be a hard thing to do, especially for Senior High School students. While doing the observation, the researcher found this phenomenon in one of the class in SMA Negeri 3 Singaraja. The researcher found that almost all of the student in that class had some difficulties in finding the main idea of certain text as well as comprehending the content of the text. Hence, the researcher concluded that it is important for a teacher to be able to find the appropriate learning strategy for the students. One of the strategies that can be used is Group Mapping Activities (GMA) strategies. Furthermore, through a classroom action research, the researcher planned to describe how the Group Mapping Activities strategy is implemented in the class. Besides, the researcher intended to prove if this strategy can really help the students to improve their reading skill including the skill of finding the main idea of certain text and comprehending the content of the text they have read. The results of the study show that the implementation of Group Mapping Activities strategy in the classroom can really facilitate and help the students in improving their reading skill. It is shown from the results of the first and second post-test given to the students that show the improvement. Moreover, from the data of the observation done by the researcher and the results of the questionnaires distributed to the students, the students showed their positive responses toward the implementation of the strategy.
\end{abstract}

\section{Pendahuluan}

Membaca merupakan salah satu jenis kemampuan berbahasa tulis yang bersifat reseptif. Disebut reseptif karena dengan membaca seseorang akan memperoleh informasi, ilmu pengetahuan, dan pengalaman-pengalaman baru. Semua yang diperoleh melalui bacaan itu akan memungkinkan orang tersebut mampu mempertinggi daya pikirannya, mempertajam pandangannya, dan memperluas wawasannya. Oleh karena itu, pembelajaran membaca di sekolah mempunyai peranan yang penting. Dalam pembelajaran membaca, guru dapat memilih wacana-wacana yang berkaitan dengan tokoh nasional, kepahlawanan, kenusantaraan, dan kepariwisataan.S elain itu melalui contoh pembelajaran membaca, guru dapat mengembangkan nilai-nilai moral, kemampuan bernalar, dan kreativitas anak didik (Irdawati; Yunidar; dan Darmawan, 2017).

Membaca juga merupakan salah satu kemampuan dasar yang wajib dimiliki oleh individu yang hidup di abad sekarang dan yang akan datang. Kemampuan membaca menjadi hal yang penting dalam suatu masyarakat sebab melalui membaca dapat diserap berbagai informasi dan wawasan pengetahuan

Copyright (C) Universitas Pendidikan Ganesha. All rights reserved. 
untuk mengembangkan peradaban masyarakat tersebut. Pentingnya kemampuan dan keterampilan membaca pada setiap orang diungkapkan oleh Burn dalam Rahim (2007: 1) bahwa "kemampuan membaca merupakan kemampuan yang mutlak dikuasai oleh masyarakat yang lebih maju" (Krismanto, Halik and Sayidiman, 2015). Membaca dapat digunakan sepanjang hidup. Membaca yang baik ditunjukkan dengan kemampuan seseorang menyelesaikan tugas membaca dengan mudah dan cepat disertai peningkatan pemahaman sehingga memperoleh nilai lebih baik dan belajar dengan cepat. Hal tersebut berdampak pada kemampuan menyelesaikan sekolah dan menjalani hidup lebih mudah (De Porter, 2003, hlm. 182). Dari uraian tersebut, menjelaskan bahwa membaca merupakan keterampilan berharga/penting sebagai bagian dari pembelajaran. Pentingnya pembelajaran membaca dituangkan dalam UU No 19 Tahun 2005 Tentang Standar Nasional Pendidikan pasal 6 ayat 5 yang berbunyi, "Kurikulum dan silabus SD/MI/SDLB/Paket A atau bentuk lain yang sederajat menekankan pentingnya kemampuan dan kegemaran membaca dan menulis, kecakapan berhitung, serta kemampuan berkomunikasi."(Khasanah and Cahyani, 2016).

Keberhasilan pendidikan dapat ditunjukkan dari kualitas pendidikan yang ada, dimana kualitas pendidikan itu meliputi kualitas proses maupun kualitas lulusan. Jadi pendidikan dikatakan berhasil apabila proses belajar- mengajarnya berjalan dengan baik serta menghasilkan output yang berkualitas. Di dalam peningkatan mutu pendidikan perlu efisiensi pendidikan, yang mempunyai arti bahwa proses pendidikan harus mencapai hasil yang maksimal dengan biaya yang wajar. Dalam pandangan yang lebih luas efisiensi pendidikan berkaitan dengan profesionalisme dan manajemen pendidikan yang di dalamnya mengandung disiplin, kesetiaan dan etos kerja. Hal ini kurang disadari oleh para penyelenggara pendidikan yang berada di daerah pada umumnya, yang pada gilirannya mengakibatkan munculnya permasalahan pada dunia pendidikan. Masalah pendidikan yang dihadapi dewasa ini yang sangat urgen adalah rendahnya mutu pendidikan pada setiap jenjang pendidikan, khususnya pada pendidikan dasar dan menengah. Berbagai usaha telah dilakukan untuk meningkatkan mutu pendidikan antara lain melalui berbagai pelatihan dan peningkatan kualitas guru, penyediaan dan perbaikan sarana prasarana pendidikan serta perbaikan kurikulum dan peningkatan mutu menajemen pendidikan sekolah (Maesaroh, 1970).

Bahasa inggris telah lama menjadi bagian yang tidak terpisahkan dari sistem pendidikan di indonesia yang pada awalnya hanya diberikan pada jenjang pendidikan yang lebih tinggi, namun seiring berjalannya waktu kebutuhan sekaligus popularitas bahasa inggris semakin meningkat yang mengakibatkan kurikulum tentang pengajaran bahasa inggris pun berubah. Dengan tujuan untuk memperbaiki kemampuan dan penguasaan bahasa inggris bagi peserta didik akhirnya pemerintah mulai mengenalkan pelajaran bahasa inggris pada jenjang pendidikan yang lebih rendah yaitu pada jenjang pendidikan dasar (Faridatuunnisa, 2020).Proses belajar Bahasa Inggris tidak sulit, akan tetapi tidak semudah membalik telapak tangan, yang penting adalah kemauan dan ketekunan. Jika kita belajar bahasa Inggrismaka kita harus sering menggunakannya. Pada umumnya akan lebih cepat menguasai Bahasa Inggris. Pada dasarnya kita sering mengaplikasikannya dalam keseharian kita, dikarenakan Bahasa Inggris telah menjadi bagian yang tidakterpisahkan dari kehidupan kita. Demikian juga yang harus kita terapkan di Indonesia, jika kita ingin belajar Bahasa Inggris dengan efektif, kita harus mengaplikasikan Bahasa Inggrissebagai bagian dari kehidupan kita. Artinya, kita harus mencoba menggunakannya setiap hari semaksimal mungkin (Nasution, D., 2021). Salah satu masalah yang menarik untuk dikaji berkaitan dengan penguasaan bahasa Inggris yang baik adalah mengenai tata bahasa (grammar). Fungsi bahasa yang utama adalah untuk berkomunikasi. Dalam berkomunikasi setiap pembicara tentulah berusaha agar apa yang ada didalam pikirannya dapat tersampaikan dengan baik dan jelas. Ia ingin agar pesannya dapat dipahami dengan baik oleh pendengar. Namun, hal ini seringkali sulit dilakukan, proses penyampaian pesan sering terhambat karena beberapa factor, misalnya adanya gangguan dan keterbatasan kemampuan bahasa (mencakup tata bahasa dan kosakata) yang sering dialami oleh pembelajar bahasa (Santosa, 2017). Berhubungan dengan pembelajaran bahasa inggris, kemampuan membaca peserta didik ditunjukkan dengan kemampuan mereka dalam memahami isi dari teks tertentu. Selain itu, mereka juga diharapkan untuk dapat menemukan informasi-informasi rinci yang terdapat dalam teks yang mereka baca. Meskipun terdengar mudah, nyatanya peserta didik masih sering mengalami kesulitan. Lebih lanjut, dengan penggunaan bahasa inggris yang berbeda dengan bahasa ibu mereka, peserta didik menghadapi kesulitan untuk menemukan informasi-informasi yang dibutuhkan dalam sebuah teks.

Berdasarkan pengamatan awal yang dilakukan di kelas X IPA 3 SMA Negeri 3 Singaraja, peneliti menemukan permasalahan yang sama. Tidak hanya sulit dalam menemukan ide pokok dari teks, peserta didik di kelas tersebut juga kesulitan dalam menjawab pertanyaan-pertanyaan yang diberikan oleh guru yang didasarkan pada teks yang telah mereka baca. Panjang dan banyaknya paragraf dalam satu teks seperti contohnya teks naratif, menjadikan kesulitan yang dihadapi oleh peserta didik terlihat dengan jelas. Kurangnya kemampuan peserta didik dalam memahami ide pokok dalam cerita membuat mereka 
juga sulit dalam memahami keseluruhan isi cerita. Oleh sebab itu, penting bagi guru untuk dapat menemukan strategi pembelajaran yang sesuai agar dapat membantu dan memfasilitasi peserta didik dalam mengasah dan atau meningkatkan kemampuan membaca teks berbahasa inggris mereka.

Salah satu strategi yang dapat digunakan adalah Group Mapping Activities (GMA). Dengan mengenalkan peserta didik dengan strategi membaca baru yang efektif, diharapkan peserta didik tidak hanya dapat menemukan infomasi yang diminta oleh guru, namun mereka juga akan mampu menemukan ide pokok dari setiap paragraf dan memahami keseluruhan cerita dalam teks.

Strategi Group Mapping Activities adalah strategi membaca yang mengarahkan dan membantu peserta didik untuk dapat memahami isi sebuah teks dengan lebih efektif. Pengimplementasian strategi ini dalam pembelajaran bertujuan untuk mengembangkan pemahaman peserta didik dengan memadukan dan menerangkan informasi, gagasan, dan konsep yang mereka dapat setelah membaca sebuah teks (Davidson, 1982). Pemahaman membaca peserta didik didapat setelah mereka memetakan atau mengelompokkan informasi-informasi yang telah mereka dapat dari teks yang mereka baca. Menciptakan kegiatan pembelajaran bahasa inggris dengan menggunakan strategi ini memungkinkan peserta didik untuk dapat bekerja secara mandiri sebaik ketika bekerja sama dalam diskusi kelompok.

Lebih lanjut, dengan keunggulan dari strategi GMA ini dalam memfasilitasi dan membantu peserta didik dalam meningkatkan kemampuan membaca bahasa inggris mereka membuat beberapa peneliti melakukan penelitian mnggunakan strategi tersebut guna mengatasi permasalahan pembelajaran yang berhubungan dengan kesulitan peserta didik dalam menguasai kemampuan membaca bahasa inggris mereka. Beberapa diantaranya adalah penelitian dari Rahman (Kurniatun, 2014). Secara singkat, melalui penelitian yang dilakukan, mereka menemukan bahwa penggunaan strategi Group Mapping Activities (GMA) di dalam kelas dapat membantu peserta didik dalam meningkatkan kemampuan membaca pemahaman mereka. Hal ini ditunjukkan dengan peningkatan nilai yang mereka peroleh dibandingkan dengan nilai-nilai yang mereka peroleh sebelum strategi ini digunakan. Selain itu, peserta didik juga merasa termotivasi dalam menjadi aktif selama proses pembelajaran berlangsung. Hal ini dikarenakan peserta didik menjadi pusat dari pembelajaran yang dilaksanakan pada hari itu.

Berdasarkan temuan di atas, peneliti bemaksud untuk melakukan penelitian tindakan kelas dengan judul "Penggunaan Strategi Group Mapping Activities (Gma) Dalam Meningkatkan Kemampuan Membaca Siswa Kelas X Ipa 3 Sma Negeri 3 Singaraja". Penelitian ini bertujuan untuk mendeskripsikan bagaimana strategi tersebut diimplementasikan di dalam kelas. Selain itu, melalui penelitian ini, peneliti juga bermaksud untuk membuktikan bahwa strategi yang telah digunakan benar-benar dapat meningkatkan kemampuan membaca bahasa inggris peserta didik di kelas X IPA 3, dimana masalah pembelajaran ditemukan.

\section{Metode}

\section{Seting Penelitian dan Subyek Penelitian}

Penelitian tindakan kelas ini dirancang untuk dilaksanakan di X MIPA 3 SMA Negeri 3 Singaraja. Lebih lanjut, penelitian ini diadakan pada semester 2 tahun ajaran 2018/2019. Alasan dari pemililihan subjek penelitian ini adalah karena pentingnya kemampuan membaca untuk dapat dikuasai oleh peserta didik dalam mempelajari bahasa inggris khususnya di tingkat sekolah menengah atas. Namun sayangnya, masih banyak peserta didik di kelas tersebut yang masih mengalami kesulitan dalam menemukan ide pokok dan memahami keseluruhan isi cerita dari teks yang telah mereka baca serta kemampuan dalam menemukan informasi-informasi tertentu.

Lebih lanjut, karena fokus penulis dalam penelitian ini adalah untuk membantu peserta didik dalam meningkatkan kemampuan membaca mereka, maka objek dari penelitian ini adalah materi pembelajaran Narrative Text.

\section{Prosedur Penelitian \\ Fase Perencanaan}

Dalam tahapan perencanaan, peneliti menyiapkan segala sesuatu yang diperlukan selama pelaksanaan penelitian tindakan kelas. Hal-hal yang dipersiapkan adalah diantaranya; RPP (Rencana Pelaksanaan Pembelajaran) termasuk langkah-langkah pembelajaran saat strategi GMA digunakan, instrumen penelitian (lembar observasi, pertanyaan untuk pre-test dan post-test, rubrik penilaian (kunci jawaban), dan lembar kuisioner).

\section{Fase Tindakan dan Observasi}

Satu siklus pada penelitian ini terdiri dari dua kali pertemuan. Pada akhir pertemuan pada setiap siklus setelah strategi telah diimplementasikan, peserta didik diberi beberapa pertanyaan berdasarkan 
teks yang telah mereka baca. Kegiatan-kegiatan pada setiap siklus menggambarkan proses belajar mengajar saat menggunakan strategi GMA.

Lebih lanjut, tahapan pengamatan berlangsung bersamaan dengan proses pembelajaran pada tahapan tindakan. Pada tahapan ini, selain memonitor dan memfasilitasi peserta didik sebagai guru, peneliti juga mengamati jalannya kegiatan belajar mengajar. Selain itu, bagaimana sikap peserta didik pada setiap kegiatan saat menggunakan strategi GMA juga akan diamati.

\section{Fase Refleksi}

Tahap refleksi terdiri dari kegiatan menganalisis hasil dari pengumpulan data selama proses pengimplementasian strategi GMA. Dari hasil analisis yang telah dilakukan, kemudian peneliti mengevaluasi penerapan strategi dengan melihat kelebihan, kekurangan, dan dampaknya dalam usaha membantu peserta didik dalam meningkatkan kemampuan membaca. Selain itu, evaluasi ini juga diperlukan untuk melakukan perbaikan pada penerapan strategi GMA yang nantinya akan diimplementasikan kembali pada siklus kedua.

\section{Teknik Pengumpulan Data}

Ada empat jenis teknik yang digunakan oleh peneliti untuk mengumpulkan data penelitian, yaitu pre-test, observasi, post-test, dan kuisioner. Lebih lanjut, teknik pengumpulan data yang pertama adalah melakukan pre-test. Tes tersebut berbentuk tes tulis dimana peserta didik diminta untuk menjawab beberapa pertanyaan berdasarkan teks naratif yang telah mereka baca. Pre-test ini juga dilakukan sebelum strategi GMA diimplementasikan.

Teknik selanjutnya yang digunakan untuk mengumpulkan data penelitian adalah observasi. Teknik ini digunakan selama strategi GMA diimplementasikan di dalam kelas. Kegiatan observasi ini dilakukan sebanyak satu kali atau dua kali bergantung seberapa lama strategi tersebut diaplikasikan dan saat target keberhasilan penelitian telah tercapai.

Teknik pengumpulan data selanjutnya, yaitu post-test, diadakan setelah strategi GMA telah selesai sepenuhnya. Sama seperti ketika pre-test, tes yang digunakan dalam post-test berbentuk tes tulis. Jenisjenis pertanyaan yang digunakan juga memiliki jenis dan tingkat kesulitan yang sama. Hal ini ditujukan agar, dari hasil tes tersebut, peneliti dapat melihat perbedaan dan atau perkembangan kemampuan membaca peserta didik.

Teknik pengumpulan data yang terakhir adalah kuisioner. Kuisioner ini dibagikan kepada peserta didik setelah hasil dari post-test telah didapat dan hasilnya telah mencapai target keberhasilan.

\section{Teknik Analisis Data}

Peneliti menganalisis data-data yang telah dikumpulkan melalui beberapa tahapan. Tahapan yang pertama adalah peneliti menganalisis data yang didapat dari hasil pre-test peserta didik. Selanjutnya peneliti menganalisis data yang diperoleh dari kegiatan observasi. Data-data yang dianalisis adalah bagaimana sikap perserta didik dalam memahami isi cerita dalam teks naratif selama strategi GMA digunakan dalam pembelajaran bahasa inggris. Menganalisis hasil post-test peserta didik menjadi langkah selanjutnya dalam menganalisis data penelitian. Langkah terakhir adalah menganalisis hasil kuisinoner yang telah dibagikan kepada peserta didik setelah hasil post-test telah diketahui dan telah mencapai target keberhasilan penelitian.

\section{Indikator Keberhasilan}

Pelaksanaan penelitian tindakan kelas ini dinyatakan berhasil apabila setelah proses analisis data, ditemukan hasil bahwa peserta didik mendapatkan peningkatan nilai dalam tes yang diberikan dan telah mencapai nilai KKM yang telah ditentukan oleh sekolah. Hal ini menunjukkan bahwa strategi yang digunakan benar-benar dapat membantu peserta didik dalam meningkatkan kemampuan membaca mereka.

\section{Hasil Dan Pembahasan}

Sebelum mengimplementasikan strategi Group Mapping Activities guna mengatasi permasalahan yang muncul di dalam kelas X IPA 3 yang menjadi hasil dari pengamatan awal, peneliti mengadakan pretest. Tujuan dari diadakannya pre-test ini adalah untuk mengecek kebenaran adanya permasalahan yang terjadi terkait kemampuan peserta didik dalam menemukan ide pokok dan memahami isi dari teks yang telah mereka baca. Selain itu, hasil dari pre-test ini juga berfungsi untuk membantu peneliti untuk mengetahui kemampuan awal dari masing-masing peserta didik di dalam kelas tersebut.

Adapun hasil dari Pre-test yang telah dilaksanakan ditunjukan pada tabel berikut; 
Tabel 1. Hasil Pre-Test

\begin{tabular}{|c|c|c|c|}
\hline No. & Nama & Skor & Kriteria \\
\hline 1 & $\mathrm{CH}$ & 50 & Fair \\
\hline 2 & GAP & 60 & Good \\
\hline 3 & GDPP & 60 & Good \\
\hline 4 & GYW & 60 & Good \\
\hline 5 & GAKLS & 50 & Fair \\
\hline 6 & INSMP & 50 & Fair \\
\hline 7 & IGAS & 70 & Good \\
\hline 8 & IKSA & 70 & Good \\
\hline 9 & IKSW & 70 & Good \\
\hline 10 & KBPP & 40 & Fair \\
\hline 11 & KBS & 40 & Fair \\
\hline 12 & KDS & 60 & Good \\
\hline 13 & KDFT & 50 & Fair \\
\hline 14 & KMP & 60 & Good \\
\hline 15 & KW & 40 & Fair \\
\hline 16 & KEW & 20 & Fair \\
\hline 17 & $\mathrm{KPF}$ & 40 & Fair \\
\hline 18 & KPDS & 70 & Good \\
\hline 19 & KSSS & 70 & Good \\
\hline 20 & LMG & 70 & Good \\
\hline 21 & LSS & 40 & Fair \\
\hline 22 & MSYDD & 50 & Fair \\
\hline 23 & NLAS & 40 & Fair \\
\hline 24 & NMYMPM & 70 & Good \\
\hline 25 & NNYDA & 60 & Good \\
\hline 26 & PHS & 40 & Fair \\
\hline 27 & PMLA & 70 & Good \\
\hline 28 & PRH & 40 & Fair \\
\hline 29 & PSP & 70 & Good \\
\hline Jumlah & & 1580 & \\
\hline
\end{tabular}

Dengan nilai KKM yang telah ditentutkan oleh pihak sekolah, yaitu 75, untuk mata pelajaran bahasa inggris, nilai yang diperoleh oleh peserta didik pada pre-test ini menunjukkan bahwa nilai mereka masih belum mencapai nilai KKM tersebut. Dari hasil pre-test di atas, peneliti menemukan nilai rata-rata kelas sebagai berikut;

$$
\begin{aligned}
\Sigma \text { Pre-Test }=1580 & \\
\text { Rata-rata nilai Pre-Test } & =\frac{\sum \text { pre-Test }}{\frac{\text { Jumlah Siswa }}{1580}} \\
& =\frac{19}{29} \\
& =54,50
\end{aligned}
$$

Berdasarkan hasil penghitungan tersebut, peneliti menyimpulkan bahwa rata-rata kemampuan membaca bahasa inggris di kelas tersebut masih belum mencapai nilai KKM yang telah ditentutkan.

\section{Siklus I}

Pelaksanaan penelitian siklus 1 terdiri dari dua pertemuan. Pada pertemuan pertama yang dilaksanakan pada hari Kamis tanggal 11 April 2019, peneliti akan melaksanakan proses pembelajaran biasa dengan menggunakan strategi yang telah dipilih, yaitu Group Mapping Activities (GMA). Strategi GMA yang digunakan pada pembelajaran siklus 1 adalah dengan model outlineing. Sehingga tujuan dari pelaksanaan pembelajaran adalah membantu peserta didik untuk dapat menemukan informasi rinci dalam teks dan menyimpulkan isi teks cerita berdasarkan outline yang telah dibuat.

Lebih lanjut, strategi GMA dengan model outlining ini digunakan selama proses pembelajaran pada kegiatan inti. Setelah guru membuka kelas, mempersiapkan peserta didik, dan menyebutkan tujuan dari pembelajaran pada hari, guru mulai membagi peserta didik ke dalam 7 kelompok dimana setiap kelompok terdiri dari 4-5 peserta didik. Kemudian guru memberikan sebuah teks dan lembar kerja pada 
masing-masing kelompok. Sebelum meminta peserta didik untuk mulai mengerjakan lembar kerja yang diberikan, guru terlebih dahulu menjelaskan tentang strategi yang akan digunakan oleh peserta didik dalam memahami teks tersebut dan apa yang harus mereka lakukan selama pembelajaran pada hari itu. Di dalam lembar kerja yang diberikan, terdapat dua task yang harus dikerjakan oleh masing-masing kelompok setelah mereka memabaca teks yang diberikan. Task yang pertama adalah melalui kegiatan diskusi berkelompok, mereka harus menuliskan informasi apa saja yang dapat mereka temukan pada masing-masing paragraf dari teks yang mereka baca. Kemudian pada task 2, tetap dalam kegiatan diskusi berkelompok, masing-masing kelompok mulai membuat outline dari teks yang mereka baca berdasarkan informasi-informasi yang telah mereka temukan. Pada kegiatan ini, guru telah menyediakan form outline yang dapat digunakan oleh masing-masing kelompok.

Setelah pelaksanaan pembelajaran siklus 1 berakhir, pada pertemuan selanjutnya peneliti mengadakan post-test dengan hasil yang dirangkum dalam tabel di bawah ini.

Tabel 2. Hasil Post-Test 1

\begin{tabular}{llll}
\hline No. & Nama & Skor & Kriteria \\
\hline 1 & CH & 70 & Good \\
2 & GAP & 90 & Very Good \\
3 & GDPP & 70 & Good \\
4 & GYW & 70 & Good \\
5 & GAKLS & 70 & Good \\
6 & INSMP & 80 & Good \\
7 & IGAS & 80 & Good \\
8 & IKSA & 90 & Good \\
9 & IKSW & 80 & Good \\
10 & KBPP & 70 & Good \\
11 & KBS & 90 & Very Good \\
12 & KDS & 80 & Very Good \\
13 & KDFT & 80 & Very Good \\
14 & KMP & 90 & Very Good \\
15 & KW & 90 & Very Good \\
16 & KEW & 80 & Very Good \\
17 & KPF & 80 & Very Good \\
18 & KPDS & 90 & Very Good \\
19 & KSSS & 80 & Very Good \\
20 & LMG & 80 & Very Good \\
21 & LSS & 90 & Very Good \\
22 & MSYDD & 70 & Good \\
23 & NLAS & 80 & Very Good \\
24 & NMYMPM & 80 & Very Good \\
25 & NNYDA & 80 & Very Good \\
26 & PHS & 70 & Good \\
27 & PMLA & 70 & Good \\
28 & PRH & 80 & Very Good \\
29 & PSP & 80 & Very Good \\
JUMLAH & & 2310 & \\
\hline & & & \\
\hline
\end{tabular}

Berdasarkan nilai yang diperoleh peserta didik pada post-test 1 , berikut adalah nilai rata-rata kelas dan presentase peserta didik yang nilainya telah mencapai nilai KKM.

$$
\begin{aligned}
& \Sigma \text { Post-Test } 1=2240 \\
& \text { Rata-rata nilai Post-Test } 1=\frac{\sum \text { Pre }- \text { Test }}{\text { Jumlah Siswa }} \\
& =\frac{2310}{29} \\
& =79,7 \\
& \text { Presentase }=\frac{\text { Jumlah Siswa dengan Nilai di atas KKM }}{\text { Jumlah Siswa }} \\
& =\frac{21}{29} \times 100 \% \\
& =72.4 \%
\end{aligned}
$$


Berdasarkan penghitungan tersebut, peneliti menemukan bahwa nilai rata-rata peserta didik menagalami peningkatan dari 54,50 menjadi 79,9. Lebih lanjut, hasil post-test 1 ini menunjukkan sebanyak 21 dari 29 peserta didik di kelas tersebut mendapat nilai di atas KKM. Sehingga presentase yang didapat adalah $72.4 \%$ peserta didik di kelas X IPA 3 telah mencapai nilai KKM. Meskipun masih terdapat 9 orang peserta didik yang nilainya masih di bawah KKM, hasil dari post-test tersebut tetap menunjukkan adanya peningkatan nilai dibandingkan dengan nilai yang diperoleh pada saat pre-test.

\section{Siklus II}

Penelitian tindakan kelas siklus 2 dengan menggunakan strategi Group Mapping Activities (GMA) dilaksanakan pada hari Kamis tanggal 25 April 2019 di kelas yang sama, yaitu kelas X IPA 3.

Jika pada pembelajaran siklus I, peneliti menggunakan outline sebagai model dari strategi yang digunakan, pada siklus ini peneliti akan menggunakan map sebagai media siswa dalam mengelompokkan informasi-informasi rinci yang telah mereka temukan dari teks yang telah mereka baca.

Setelah guru menujukkan beberapa contoh map yang dapat digunakan oleh peserta didik, guru mulai membagi peserta ke dalam 7 kelompok dengan 4-5 orang peserta didik pada setiap kelompoknya. Masing-masing kelompok akan mendapatkan teks baru, lembar kerja siswa, dan juga selembar kertas kosong dimana mereka akan menggambarkan map mereka. Setelah guru menjelaskan apa yang harus dilakukan peserta didik di dalam kelompok masing-masing, guru mengarahkan peserta didik untuk mulai mengerjakan lembar kerja mereka melalui kegiatan diskusi berkelompok. Dalam pembelajaran ini, peserta didik diminta untuk menemukan informasi-informasi penting yang ada di masing-masing paragraf dari teks yang telah diberikan. Kemudian, mereka mengelompokkan informasi-informasi tersebut berdasarkan unsur intrinsik dari sebuah cerita. Dari pengelompokkan informasi ini, kemudian secara individu, mereka buat menjadi map sesuai dengan daya kreativitas mereka masing-masing.

Pada pertemuan selanjutnya, peneliti mengadakan post-test ke dua. Pada pelaksanaannya, peneliti menmukan hasil sebagai berikut;

Tabel 3. Hasil Post-Test 3

\begin{tabular}{|c|c|c|c|}
\hline No. & Nama & Skor & Kriteria \\
\hline 1 & $\mathrm{CH}$ & 78 & Very Good \\
\hline 2 & GAP & 82 & Very Good \\
\hline 3 & GDPP & 78 & Very Good \\
\hline 4 & GYW & 89 & Very Good \\
\hline 5 & GAKLS & 82 & Very Good \\
\hline 6 & INSMP & 88 & Very Good \\
\hline 7 & IGAS & 83 & Very Good \\
\hline 8 & IKSA & 80 & Very Good \\
\hline 9 & IKSW & 94 & Very Good \\
\hline 10 & КВРP & 76 & Very Good \\
\hline 11 & KBS & 78 & Very Good \\
\hline 12 & KDS & 78 & Very Good \\
\hline 13 & KDFT & 80 & Very Good \\
\hline 14 & KMP & 88 & Very Good \\
\hline 15 & KW & 80 & Very Good \\
\hline 16 & KEW & 85 & Very Good \\
\hline 17 & $\mathrm{KPF}$ & 85 & Very Good \\
\hline 18 & KPDS & 85 & Very Good \\
\hline 19 & KSSS & 88 & Very Good \\
\hline 20 & $\mathrm{LMG}$ & 100 & Very Good \\
\hline 21 & LSS & 83 & Very Good \\
\hline 22 & MSYDD & 76 & Very Good \\
\hline 23 & NLAS & 80 & Very Good \\
\hline 24 & NMYMPM & 78 & Very Good \\
\hline 25 & NNYDA & 80 & Very Good \\
\hline 26 & PHS & 78 & Very Good \\
\hline 27 & PMLA & 82 & Very Good \\
\hline 28 & PRH & 76 & Very Good \\
\hline 29 & PSP & 86 & Very Good \\
\hline \multicolumn{2}{|c|}{ JUMLAH } & 2396 & \\
\hline
\end{tabular}


Nilai rata-rata kelas dan presentase peserta didik yang nilainya telah mencapai nilai KKM berdasarkan nilai yang diperoleh peserta didik pada post-test 2 adalah terhitung sebagai berikut;

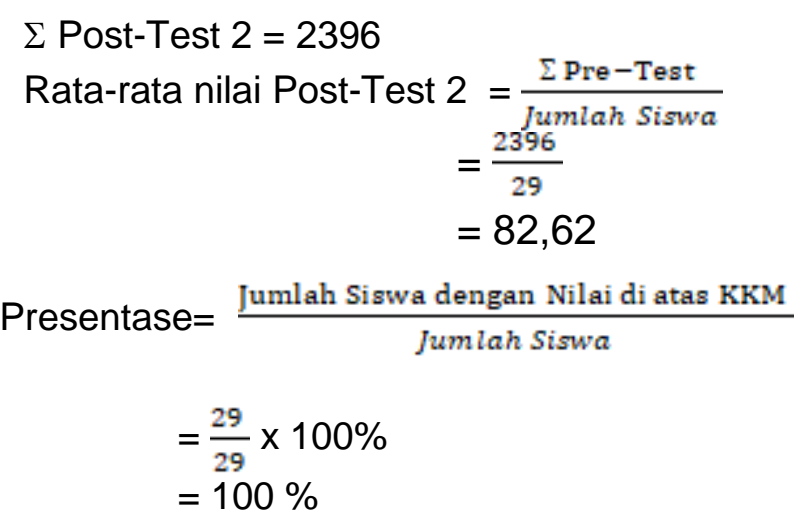

Hasil perhitungan di atas menunjukkan nilai rata-rata kelas yang meningkat sebesar 2,92. Sebanding dengan nilai rata-rata kelas yang meningkat, presentase kecapaian peserta didik terhadap nilai KKM juga mengalami peningkatan. Berdasarkan perhitungan yang telah dilakukan, presentase pencapaian peserta didik terhadap nilai KKM adalah $100 \%$. Hal ini menunjukkan bahwa seluruh peserta didik di kelas X IPA 3 berhasil memperoleh nilai di atas KKM pada post-test 2.

\section{Observasi \& Kuisioner}

Selama proses pembelajaran siklus I dan II ketika strategi Group Mapping Activities (GMA), selain menjadi guru pengajar, peneliti juga bertindak sebagai observer atau pengamat. Selama pembelajaran berlangsung, peneliti beberapa kali berkeliling ruang kelas dan mengunjungi masing-masing kelompok untuk mengecek kinerja mereka dalam mengerjakan tugas-tugas yang diberikan. Selain itu, peneliti juga sesekali berinteraksi dengan peserta didik guna mengecek pemahaman peserta didik terhadap teks yang mereka baca.

Berdasarkan hasil pengamatan, peneliti menemukan bahwa penggunaan strategi ini peserta didik menunjukkan respon yang positif. Diantara respon positif yang ditunjukkan oleh peserta didik selama proses pembelajaran adalah peserta didik menjadi lebih aktif dalam berkomunikasi satu sama lain dalam proses diskusi kelompok, peserta didik menjadi lebih termotivasi untuk bertanya baik untuk menanyakan infromasi dalam teks yang belum mereka pahami atau hanya untuk mengkonfirmasi pemahaman mereka terhadap informasi-informasi tersebut, dan peserta didik menjadi lebih cepat dalam memahami alur cerita dalam teks yang telah mereka baca.

Lebih lanjut, setelah peneliti menganalisis hasil post-test 2 yang hasilnya menunjukkan bahwa penelitian ini telah memenuhi kedua indikator keberhasilan dari penelitian ini, pada pertemuan selanjutnya, peneliti menyebarkan kuisioner pada seluruh peserta didik di kelas tersebut. Hasil dari analisis respon peserta didik terhadap kuisioner yang dibagikan telah dirangkum dalam tabel di bawah ini;

Tabel 4. Hasil Kuisioner

\begin{tabular}{|c|c|c|c|c|c|}
\hline \multirow{2}{*}{ No. } & \multirow{2}{*}{ Pernyataan } & \multicolumn{4}{|c|}{ Jumlah Peserta Didik } \\
\hline & & SS & $\mathbf{S}$ & $\mathbf{R}$ & TS \\
\hline 1. & $\begin{array}{lr}\text { Strategi membaca GMA } & \text { sangat } \\
\text { memudahkan saya dalam } \\
\text { menemukan informasi rinci } \\
\text { dalam teks cerita yang saya baca. }\end{array}$ & 8 & 20 & 1 & \\
\hline 2. & $\begin{array}{l}\text { Strategi membaca GMA } \\
\text { membantu saya dalam } \\
\text { mengelompokkan informasi yang } \\
\text { saya temukan dalam teks cerita } \\
\text { yang saya baca. }\end{array}$ & 4 & 23 & 2 & \\
\hline 3. & $\begin{array}{l}\text { Strategi membaca GMA sangat } \\
\text { membantu saya dalam } \\
\text { memahami keseluruhan isi dari } \\
\text { teks cerita yang saya baca. }\end{array}$ & 6 & 15 & 8 & \\
\hline
\end{tabular}




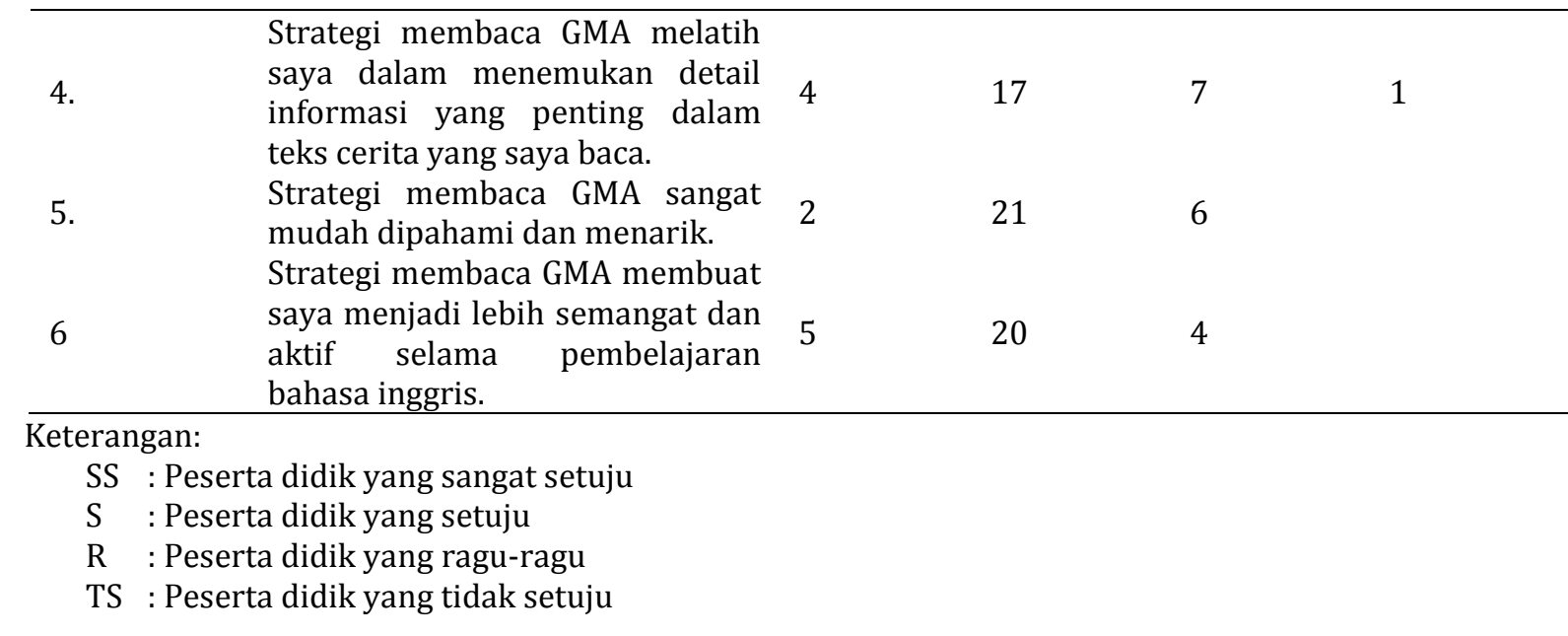

Berdasarkan data kuisioner di atas, peneliti dapat menyimpulkan bahwa dari 29 peserta didik di dalam kelaslebih dari 50\% peserta didik setuju bahwa penggunaan strategi Group Mapping Activities dapat membantu mereka dalam menemukan informasi rinci dalam sebuah teks, memahami kesluruhan isi teks yang dibaca, dan memotivasi mereka untuk menjadi lebih aktif dalam mengikuti kegiatan pembelajaran.

Lebih lanjut, sebagian besar peserta didik memberikan penjelasan tentang bagaimana strategi yang digunakan berdampak pada mereka selama proses pembelajaran berlangsung. Pada pertanyaan tentang bagaimana strategi GMA ini dapat membantu mereka selama pembelajaran berlangsung, sebagian besar peseta didik di kelas X IPA 3 menjawab bahwa ketika mereka menggunakan strategi ini mereka merasa lebih mudah dalam menemukan informasi rinci yang dibutuhkan dan ebih mudah dalam memahami keseluruhan isi teks cerita yang dibaca. Selain itu, mereka juga menjawab bahawa mereka merasa ebih termotivasi untuk menjadi lebih aktif selama pembelajaran berlangsung ketika strategi ini digunakan.

\section{Simpulan}

Berdasarkan Penelitian tindakan kelas ini dilaksanakan karena munculnya masalah pembelajaran di kelas X IPA 3 SMA Negeri 3 Singaraja setelah dilakukannya pengamatan awal. Masalah yang muncul adalah bahwa kemampuan membaca bahasa inggris dari hampir seluruh peserta didik di kelas tersebut masih terbilang kurang. Lebih spesifik, permasalahan pembelajaran yang dihadapi oleh peserta didik di kelas tersebut adalah kemampuan mereka dalam menemukan ide pokok dan memahami isi dari sebuah teks Lebih lanjut, dengan menggunakan strategi Group Mapping Activities (GMA) peneliti mencoba untuk mengatasi permasalahan pembelajaran yang terkait dengan kemampuan membaca bahasa inggris peserta didik tersebut. Dari hasil pre-test, post-test 1, post-test 2, dan pengamatan selama proses pembelajaran serta hasil kuisioner, peneliti dapat menyimpulkan bahwa pengimplementasian strategi GMA di dalam kelas tersebut benar-benar dapat membantu peserta didik dalam meningkatkan kemampuan membaca bahasa inggris mereka yang meliputi kemampuan menemukan ide pokok dan memahami keseluruhan isi cerita dari teks yang telah mereka baca. Hal ini dibuktikan dari hasil nilai yang terus mengalami peningkatan hingga seluruh peserta didik di dalam kelas tersebut dapat memperoleh nilai diatas KKM yang telah ditentukan. Selain itu, peserta didik juga menunjukkan respon positif terhadap strategi yang digunakan oleh guru di dalam kelas. Hal ini ditunjukkan dengan keaktifan peserta didik dalam mengikuti setiap tahapan kegiatan pembelajaran di dalam kelas.

\section{Daftar Pustaka}

Faridatuunnisa, I. (2020) 'Kebijakan Dan Pelaksanaan Pembelajaran Bahasa Inggris Untuk Sd Di Indonesia.', Seminar Nasional Pendidikan, Pp. 191-199. Available At: Https://Jurnal.Ustjogja.Ac.Id/Index.Php/Semnas2020/Article/View/7510.

Irdawati; Yunidar; Dan Darmawan (2017) 'Meningkatkan Kemampuan Membaca Permulaan Dengan Menggunakan Media Gambar Kelas 1 Di Min Buol, Issn 2354-614x', Jurnal Kreatif Tadulako Online, 5(4), Pp. 1-14. Available At: Http://Jurnal.Untad.Ac.Id/Jurnal/Index.Php/Jkto/Article/View/2918.

Khasanah, A. And Cahyani, I. (2016) 'Peningkatan Kemampuan Membaca Pemahaman Dengan Strategi Question Answer Relationships (Qar) Pada Siswa Kelas V Sekolah Dasar', Jurnal Pedagogik Pendidikan Dasar, 4(4), Pp. 161-175. Available Https://Ejournal.Upi.Edu/Index.Php/Ppd/Article/Download/6468/4411\%0a.

Krismanto, W., Halik, A. And Sayidiman, S. (2015) 'Meningkatkan Kemampuan Membaca Pemahaman 
Melalui Metode Survey, Question, Read, Recite, Review (Sq3r) Pada Siswa Kelas Iv Sd Negeri 46 Parepare', Publikasi Pendidikan, 5(3). Doi: 10.26858/Publikan.V5i3.1616.

Kurniatun, I. (2014) Keefektifan Strategi Gma (Group Mapping Activities) Dalam Pembelajaran Membaca Pemahaman Cerita Anak Pada Siswa Kelas Vii Di Smp Sanden Bantul. Bantul.

Maesaroh, S. (1970) 'Peranan Metode Pembelajaran Terhadap Minat Dan Prestasi Belajar Pendidikan Agama Islam', Jurnal Kependidikan, 1(1), Pp. 150-168. Doi: 10.24090/Jk.V1i1.536.

Nasution, D., Harahap, S., Siregar, S., \& Hasibuan, A. (2021) 'Pendampingan Bahasa Inggris Pada AnakAnak Setingkat Sekolah Dasar Di Desa Wisata Pagaran Gala- Gala, Mandailing Natal- Sumut, Dalam Mengahadapi Masyarakat Ekonomi Asean (Mea) Melalui Metode Drilling Dan Repetition', Jurnal Pengabdian Kepada Masyarakat, 1(2), 63-72. Retrieved from https://stp-mataram.ejournal.id/Amal/article/view/573.

Santosa, P. P. P. (2017) 'Kemampuan Membaca Teks Persuasif Bahasa Inggris Siswa Kelas X Smk Negeri 2 Depok (The Ability To Read Text United Kingdom Language Grade Persuasive X Smk Negeri 2)', Deiksis, 09(02), Pp. 170-181. 